\title{
Waking (for) the Nation: Immaterial Materialism and the Feminine Body in Tom Murphy's The Wake (1998)
}

\section{Moonyoung Hong}

\section{(2) OpenEdition}

\section{Journals}

Electronic version

URL: https://journals.openedition.org/etudesirlandaises/10664

DOI: 10.4000/etudesirlandaises. 10664

ISSN: 2259-8863

Publisher

Presses universitaires de Caen

Printed version

Date of publication: 8 July 2021

Number of pages: 107-122

ISBN: 978-2-38185-030-6

ISSN: 0183-973X

\section{Electronic reference}

Moonyoung Hong, "Waking (for) the Nation: Immaterial Materialism and the Feminine Body in Tom Murphy's The Wake (1998)", Études irlandaises [Online], 46-1 | 2021, Online since 08 July 2021, connection on 14 November 2022. URL: http://journals.openedition.org/etudesirlandaises/10664 ; DOI: https://doi.org/10.4000/etudesirlandaises.10664

\section{(c) (i) (9)(2)}

Creative Commons - Attribution-NonCommercial-ShareAlike 4.0 International - CC BY-NC-SA 4.0 https://creativecommons.org/licenses/by-nc-sa/4.0/ 


\title{
Waking (for) the Nation: \\ Immaterial Materialism and the Feminine Body in Tom Murphy's The Wake (1998)
}

\begin{abstract}
The paper examines Tom Murphy's play The Wake and the significance of its staging as part of the Abbey Theatre's 1916 centenary "Waking the Nation" programme. The play critiques the process by which various elements of capitalism - in particular materialistic culture, bourgeois morality and hypocrisy - combine to commodify, repress and eliminate the human body. Murphy suggests that the pitfalls of materialism point to the ironic truth that it denies the substantive materiality to our bodily existence. The female body in particular is continually subjected to violence and exploitation. By dramatising the emotional consequences of this immaterial materialism through the lens of a marginalised female émigré and sex worker, the play contests and subverts the woman / nation figurations in the context of Irish literary, theatrical and cultural imagination. The meaning of the wake ritual is revisited and experienced as a temporary celebration of theatre as community.
\end{abstract}

Keywords: Tom Murphy, materialism, commemoration, gender, body, wake, Irish theatre.

Résumé: Cet article examine la pièce de théatre de Tom Murphy, The Wake, et l'importance de sa mise en scène dans le cadre du programme du centenaire de 1916 de l'Abbey Theatre "Waking the Nation». La pièce critique les effets du capitalisme - de la culture matérialiste, de la morale bourgeoise et de l'hypocrisie - qui réifie, réprime et élimine le corps humain. Murphy suggère que les écueils du capitalisme soulignent une vérité ironique où la matérialité substantielle de notre existence corporelle est niée. Le corps féminin en particulier est continuellement soumis à la violence et à l'exploitation. En mettant en scène les conséquences émotionnelles de ce matérialisme immatériel à travers le prisme d'une travailleuse du sexe immigrée et marginalisée, la pièce conteste et subvertit les figurations femme/nation dans le contexte de l'imaginaire littéraire, théâtral et culturel irlandais. Le sens du rituel de la veillée funèbre est revisité et vécu comme une célébration temporaire du théâtre en tant que communauté.

Mots clés: Tom Murphy, matérialisme, commémoration, sexe, corps, veillée funèbre, théâtre irlandais.

Tom Murphy's play The Wake (1998) is a dramatic reworking of his own novel The Seduction of Morality (1994) which deals with a female émigré's return from the United States to her hometown ${ }^{1}$. After decades of economic and cultural selfisolation, Ireland began to change its policies from the late 1950s: T. K. Whitaker

1. Tom Murphy, The Wake, in Plays. 5, London, Methuen Drama, 2006. All subsequent references are included parenthetically in the text. 
launched Ireland's first programme for economic expansion in 1958, and in 1973, Ireland successfully joined the European Economic Community (EEC). Ireland's economic development would reach its peak in the 1990s during the Celtic Tiger era of an unprecedented, new-found wealth ${ }^{2}$. In both the novel and the play, Murphy critiques the rampant materialism and bourgeois morality that lies at the heart of modern Irish society. In an interview with Alice Freeman, Murphy explained the novel's title and what "Irish morality" entails:

If you take anyone and ask them what the first thing is that they associate with seduction, it's sex. [...] In Ireland if you mention the word morality, it means sex. [...] There is more to life and behaviour than just sex. I am playing on the two words [...]. You have people who will be seduced by the idea of respectability, the type of so-called moral values which allow them to say they never tell a lie in their life, though in fact their lives may be complete lies ${ }^{3}$.

Murphy reverses the connotation behind the terms, "seduction" and "morality"; "morality", as its own idea, seduces and deceives, while "sex" speaks its own truth.

The Wake follows the tale of a sex worker named Vera, who - after working as a prostitute in New York - returns to her home in the West of Ireland for what she thinks is to be a funeral, to pay respects to her grandmother Mom. Upon her arrival, Vera finds out that Mom died many months ago and that her family kept the news from her. Added to Vera's anguish is the fact that Mom has not been given a proper wake. A series of examples of her family's brutality and deliberate neglect of Mom is revealed: not only did the family pressure Mom into signing over the farm, withdrawing young Vera from her care when she refused to do so many years ago, but they also forbade her neighbours from visiting Mom which caused Mom's premature death. The O'Tooles are only interested in acquiring the hotel that Vera has inherited. They justify their greed in moral terms as Vera's unchaste behaviour offends and threatens their "respectability". Vera becomes finally unbearable to them when she performs a public drunken orgy at the hotel with Finbar, her former boyfriend, and Henry, her brother-in-law. Vera is then kidnapped and taken to a mental hospital. Released from the hospital, she makes a deal with her family and gathers them at the hotel for a wake. At the end, she

2. See Diarmaid Ferriter, The Transformation of Ireland, New York, Overlook, 2005, p. 623-759. During the Celtic Tiger, the creation of new jobs averaged more than 1,000 a week between 1994 and 2000. There were 1.71 million people employed by 2000 up from 1.08 million in 1986, and Irish non-agricultural growth at 26 per cent exceeded that of the 12 European Union countries (only 7 per cent growth). The productivity record consistently outperformed its partners in the European Union. Nevertheless, "The overwhelmingly positive media reporting of the economy, both at home and abroad, [...] encouraged a lack of critical thought as to how the money should be spent, or what constituted sustainable or holistic development. [...] the increase in inequality in Ireland could not be denied. [...] the top 10 per cent of households held one half of the total wealth, and the top 5 per cent about 20 to 25 per cent" (ibid., p. 675).

3. Alice Freeman, "Murphy's Laws About Women: The Seduction of Morality", Daily Express, 29 August 1994, in “Tom Murphy Collection: Reviews \& Correspondence”, Trinity College, Dublin, Ireland, IE TCD MS11115/6/2/19/2. 
generously hands over the hotel to the family and leaves her home place for good, accepting her loneliness as inexorable. In the play, materialism disrupts familial values; economic greed replaces human intimacy to the point where Vera becomes part of a business deal.

When Murphy was redrafting the novel into a play, he originally intended to keep the 1970s setting; however, he realised that the play was still relevant to the 1990s and used that later era as the locus of the play ${ }^{4}$. Re-situating the play speaks strongly to contemporary audiences and contributes greatly to the politics of performance. Interestingly enough, not only do the twenty years roughly parallel the time span between the play's premiere and its revival in 2016, but the period also covers the spectacular rise, fall and aftermath of the Celtic Tiger era. The 2016 Abbey production directed by Annabelle Comyn called attention to the history of Ireland and the current state of affairs as part of the 1916 centenary and "Waking the Nation" programme. In the programme note, Gary Keegan comments that "this Abbey Theatre production of The Wake is timely as we continue to pick up the pieces of the economic crash", offering an opportunity to "redefine our values" 5 . These values reflect feminist concerns; the line-up of the centenary programme itself was controversial and the \#WakingTheFeminists campaign followed, opposing the Abbey's choice of staging plays predominantly by male playwrights and male directors ${ }^{6}$. In Irish theatre, the prominence of literary texts resulted in the relative neglect of bodies in general and female bodies in particular. Shonagh Hill posits that "the elision of female experience and of female bodies have been perpetuated by Irish theatre, and the study of it, as a predominantly literary theatre tradition"'. Murphy, whose works stand within the Irish literary theatre tradition, is thus an important case study; although a male playwright himself, Murphy (and the Abbey production of his play) explores the same issues - of the feminine body and materialism - that expose and condemn the mechanisms by which women are alienated and marginalised. If Hill's way of "fine-combing the past" is to retrieve a (non-essentialist) genealogy of women's voices and experiences in Irish theatre history by focusing solely on female writers, theatre-makers and performers, this paper further interrogates the possibility of taking into account female bodies strongly rooted in language, giving the neglected bodies their due both in literary and performative practice. In The Wake, Murphy exposes the irony that materialism and material culture - which is comprised of objects and object-fetishism - erases the materiality of the body. More than anything else, the staged performances revealed the culture of repression and the institutions arising from such erasure of the body - a thing regarded as lustful and in need of discipline. This paper analyses the 2016 Abbey production of The Wake examining

4. For more details about the evolution of the text, see Nicholas Grene, The Theatre of Tom Murphy: Playwright Adventurer, London, Bloomsbury, 2017, p. 91-93.

5. Gary Keegan, programme note, "If These Walls Could Talk", The Wake, Abbey Theatre Dublin, 22 June-30 July 2016, p. 9.

6. See http://www.wakingthefeminists.org/about-wtf/how-it-started.

7. Shonagh Hill, Women and Embodied Mythmaking in Irish Theatre, Cambridge, Cambridge University Press, 2019, p. 7. 
the ways in which Murphy's drama of material(istic) emotion was staged, and how it was realised by Comyn's directorial intervention.

\section{Materialism(s) and bodies}

The Wake reflects Ireland as a materialistic society driven by the cultural logic of capitalism and neoliberalism. According to Terry Eagleton, the problematic logic of capitalism lies in the Cartesian dichotomy embedded in the common usage of the term "materialism". In Materialism (2016), Eagleton addresses the mind-body problem. He writes that bodies are

[...] chunks of matter of a highly specific kind - a specificity which mind-language or soul-language seeks rather misleadingly to pin down. They are not lumps of natural stuff with some ghostly appendage attached to them, but mounds of material which are inherently active, creative, communicative, relational, self-expressive, self-realising, world-transforming and self-transcendent (which is to say, historical) ${ }^{8}$.

The logic of capitalism relies on the mind-body dualism, which enables the process of abstraction and the erasure of the sensuousness of the body. In Eagleton's view, bodies are expressive subjects and humans are "historical beings" in a "peculiarly animal way"; in other words, history, culture and society are "specific modes

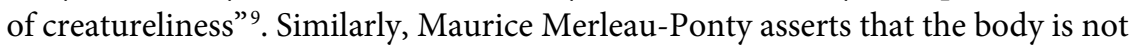
an entity to which meaning is ascribed, but a "body-subject". As he puts it, "the union of body and soul is not an amalgamation between two mutually external terms, subject and object, brought about by arbitrary decree"; rather, "it is enacted at every instant in the movement of existence" ${ }^{10}$. Such lived experience and corporeal knowledge are critical in feminist studies. Elizabeth Grosz and Iris Marion Young note how female bodies are limited by being made mere objects; at the same time, as free subjects, they challenge cultural norms ${ }^{11}$.

Judith Butler regards bodies as a process that stabilises and materialises over time ${ }^{12}$, and stresses the importance of considering the body in relation to gender, challenging all dualisms: not only of the mind-body, but also of inner/outer and subject/ object regarding the body. In Gender Trouble: Feminism and the Subversion of Identity (1990), Butler writes: "Just as bodily surfaces are enacted as the natural,

8. Terry Eagleton, Materialism, New Haven, Yale University Press, 2016, p. 39.

9. Ibid., p. 44-45.

10. Maurice Merleau-Ponty, Phenomenology of Perception, Colin Smith (trans.), London, Routledge, 1962, p. 102.

11. Elizabeth Grosz, Volatile Bodies: Towards a Corporeal Feminism, Bloomington, Indiana University Press, 1994; Iris Marion Young, On Female Body Experience: "Throwing Like a Girl" and Other Essays, Oxford, Oxford University Press, 2005.

12. Judith Butler, Bodies That Matter: On the Discursive Limits of "Sex", New York, Routledge, 1993. Butler claims that "to be material means to materialize, where the principle of that materialization is precisely what 'matters' about that body, its very intelligibility" (ibid., p. 7). 
so these surfaces can become the site of dissonant and denaturalized performance that reveals the performative status of the natural itself" ${ }^{13}$. While Butler's example pertains to the performance of drag as a way to create dissonance of gender binaries, Murphy's appropriation and dramatisation of female characters raises questions over their "feminine" bodies - in their immobility, oppression, abuse, mistreatment, commodification and dissociation - and their identities. By representing their voices and bodies in the fictional and theatrical world, Murphy himself performs sex / gender by adopting "feminine" constructs - words, act, gesture and desire - and in effect reveals the performativity of gender and the "profound unnaturalness" of bodies embedded in the materialisation process. Butler elaborates:

As the effects of a subtle and politically enforced performativity, gender is an "act," as it were, that is open to splittings, self-parody, self-criticism, and those hyperbolic exhibitions of "the natural" that, in their very exaggeration, reveal its fundamentally phantasmatic status ${ }^{14}$.

The Wake presents the phantasmatic status of the body in its theatricality and in its staged performance. The theatre provides the space for the characters' complex relation to their bodies and sense of self to materialise in the process (and presence) of the actors-as-characters act(ing) on stage. Theatre as a commercial institution can be both complicit in and resistant to the commodification of bodies. By exhibiting the abject, grotesque and carnivalesque female body, whereby the main actor-as-character performs her sexuality in public, The Wake resists and critiques the capitalist drive for abstraction and commodification, alerting the audience to the realities of bodily consciousness.

\section{Staging the hotel, performing the body}

From this "materialist(ic)" perspective, it is most pertinent that the contestation between the commodification of bodies and their resistance to it takes place in the space of the hotel, which is the main setting of The Wake. The name of the hotel - The Imperial Hotel ${ }^{15}$ - is itself deeply suggestive. Henry regards The Imperial Hotel as "this jewel in the crown of the family fortunes" (p. 109). A Georgian building and once a family residence, the hotel can easily be linked to the Big Houses in Ireland. From the early 1920s up to the 1980s, Big Houses were sold off or destroyed, leading to the decline of the "Big House era" which had marked the political dominance of

13. Judith Butler, Gender Trouble: Feminism and the Subversion of Identity, New York, Routledge, 1990, p. 146.

14. Ibid., p. 147.

15. The Imperial Hotel was in fact the name of the hotel in Murphy's hometown of Tuam, the basis for the play's setting. It is situated in the Square, in the town centre of Tuam. In the Irish Historic Towns Atlas (IHTA) - Tuam, it is listed as Daly's hotel (1832-1856), Daly's Royal Mail Hotel (1878), and Daly's Royal Hotel (1881), becoming Guy's Imperial Hotel in 1892 through 1894, and Corralea Court Hotel in 2009. 
the Anglo-Irish class since the late $16^{\text {th }}$ century. In the present day, Big Houses have undergone such profound changes not only in ownership but in social function that their lineage and history no longer matter ${ }^{16}$. The O'Tooles are Catholic and none of them are interested in the history of the house; Tom, for instance, only wants to resell the hotel for profit. Henry - whose last name Locke-Brown is an indicator of his "mixed-blood" heritage - is a Catholic but also a Protestant with "protesting genes: my mother's side, the Lockes" (p. 131). As the last decadent heir, he is the only figure who connects with the past. Despite his partial alliance with Vera, however, he is unable to sever his tribal ties: "Culture has defeated him" (p. 97) and he is trapped in his role as husband to Marcia and father to Norman. Neither "imperial" nor "crown" resonates with the O'Tooles. Their language is the language of capitalism whose grammar is structured around commodity and profit. In an "independent" Ireland, capitalism has become another form of imperialism.

The hotel as an embodied form of capital can be traced back to its earliest origins; it is a space of commercial hospitality, where privacy is guarded and disguised in public. Compared to other lodgings that accommodated travellers, hotels reflect the changing milieu of greater commercialisation and modernisation. Hotels proliferated in the early $19^{\text {th }}$ century in Western Europe to accommodate richer customers ${ }^{17}$. Modern day hotels attest to the further shift towards what Marc Augé coins as "non-place", where anonymity and transience are its defining features. The word "non-place" designates

[...] two complementary but distinct realities: spaces formed in relation to certain ends (transport, transit, commerce, leisure), and the relations that individuals have with these spaces. [...] anthropological places create the organically social, so non-places create solitary contractuality ${ }^{18}$.

Non-places are effects of "supermodernity" and The Wake reflects the rapid process of modernisation in Ireland ${ }^{19}$. The consequences of "supermodernity" - uneven and incoherent development in society - contribute to the sense of confusion and contradiction for people living through those rapid changes.

The tide of modernisation clashes with the moralities and sensibilities of Vera's small town. The meaning of the small-town mentality is detailed in the novel

16. Terence Dooley, "Irish Big Houses: Introduction to the Historiography of the Irish Big House", in The Big Houses and Landed Estates of Ireland: A Research Guide, Dublin, Four Courts Press, 2007, p. 137.

17. See Elaine Denby, Grand Hotels: Reality and Illusion. An Architectural and Social History, London, Reaktion, 1998; and Nikolaus Pevsner, A History of Building Types, Princeton, Princeton University Press, 1976.

18. Marc Augé, Non-Places: Introduction to an Anthropology of Supermodernity, John Howe (trans.), London, Verso, 1995, p. 94.

19. Ibid., p. 103. Augé defines supermodernity as having "three figures of excess: overabundance of events, spatial overabundance and the individualization of references" (ibid., p. 109) and making "the old (history) into a specific spectacle, as it does with all exoticism and all local particularity" (ibid., p. 110). 
and the manuscript drafts of the play. When Vera is still living in New York, not having replied to her family's request to deal with the hotel matter, her brother Tom sends her a passive-aggressive letter. He takes "the opportunity of her absence to wax moral":

I do not know what you think you are playing at over there, but your sisters and I would also like to ask have you forgotten what it is like to live in a small town? - And the pride we take in it. New York indeed and I am sure is New York, but a name means something here. We have a sense of place. We have a sense of responsibility - we aspire to become moral agents without apologies to anyone, because that is our greatest desire, Vera ${ }^{20}$.

The family's outmoded "sense of place", evident in their insistence on reputation and traditional morality, clashes with the ideas of modernity, progress and anonymity associated with "supermodernity". Murphy finds both the outmodedness of tradition and dehumanising traits of "non-place" absurd.

This mismatch of sensibility and economic condition can be considered distinctly "Irish", in the context of the Celtic Tiger: a collective but contradictory representation of Ireland in the booming economy of the 1990s. Kieran Keohane and Carmen Kuhling discuss how the use of "Celtic" as opposed to "Irish" connotes a "remote, primordial history, a pre-national history [...] a romantic, spiritual, unified sense of history [...] a desire to transcend history" ${ }^{21}$. In contrast, the term "Tiger" invokes "the rhetoric of competitive individualism and its attendant ideology of survival of the fittest", signifying the economic prowess of neoliberalism ${ }^{22}$. As opposed to the ideologically informed economic projects in Britain (led by Thatcher) and the United States (led by Reagan),

[...] the Irish political landscape [has] produced a certain species of neoliberalism in Ireland which is perhaps best characterised as ideologically concealed, piecemeal, serendipitous, pragmatic, and commonsensical. Indeed, successive Irish governments have never had an explicit neoliberal ideology (apart from a small number of influential ministers) [...]. And yet Ireland was characterised [...] by a range of practices which bear important similarities discursively and materially with key processes of neoliberalisation [...]. Irish neoliberalism was produced through a set of shortterm (intermittently reformed) deals brokered by the state with various companies, individuals, and representative bodies, which cumulatively restructured Ireland in unsustainable and geographically "uneven" ways ${ }^{23}$.

20. Manuscript draft of The Wake/ "Whoresplay", in "Tom Murphy Collection: Produced Plays", Trinity College, Dublin, Ireland, IE TCD MS11115/1/23/2a-b.

21. Kieran Keohane, Carmen Kuhling, "What Was the 'Celtic Tiger'?", in Collision Culture: Transformations in Everyday Life in Ireland, Dublin, Liffey, 2004, p. 146.

22. Ibid., p. 149-150. The tiger is also a direct reference to the Asian economies that had produced a rapid modernisation and massive rates of growth in economies that had long been under-developed.

23. Rob Kitchin, Cian O'Callaghan, Mark Boyle, Justin Gleeson, Karen Keaveney, "Placing Neoliberalism: The Rise and Fall of Ireland's Celtic Tiger”, Environment and Planning A, vol. 44, 2012, p. 1306. 
The ideologically concealed but nonetheless forceful neoliberal changes in Irish socio-cultural history as well as its "uneven" geographical development can be linked to the ambivalent aspects in the performance of the play. Values collided in the space presented on stage and suggested the anxiety and fear of being caught between the binaries of past / future, collectivism/individualism and spiritual/material. The 2016 production of The Wake presented a "semi-abstract" and "mythic" stage to evoke a ghostly and liminal landscape ${ }^{24}$. Set designer Paul O’Mahony kept the hotel setting minimal, with only the red carpet, vintage chairs and long candlesticks to occupy the dark empty space. The hotel did not exude glamour or splendour; instead, its space was filled with vast darkness. The symbolic gestures created a sense of hollowness, changing the temperature of the plain realism that often (mistakenly) defines Murphy's naturalism. The overall effect of this ghostliness underscored the nature of materialism and the ways in which it de-materialises human bodies.

The hotel encapsulates the effects of capitalism on the family and serves as a metaphor for their hypocrisy. Vera is "the" prostitute who worked as a call-girl in New York; however, it is not so much Vera's disreputable past as the O'Toole family's rapaciousness that transforms the hotel into a whorehouse. As Alexandra Poulain explains, "for all its display of quaint traditionalism, the Ireland of the 1990 s is really just a whorehouse, moved only by the spirit of acquisitiveness" 25 . When Finbar hits Vera, calling her a "cunt", she responds:

Fuck me, screw me, rook me - if-you-are-able! - but don't anyone of you insult me like this! Okay? ... I'm someone, amn't I? ... Who-what am I? A hole between my legs? ... I'm not a cunt ... (I'm) Someone. [...] on my own then - [...] Who is the whore? Quem, cunt, ghee, box, slash, gash, cock-sucking, grandmother-fucking piece of shit, daff, crap, excrement? [...] All dirt and lies. (p. 119)

Vera threatens Finbar with the rhetorical question "Who is the whore?" multiple times over. Her rage subverts their respective positions: Vera's dress and appearance identify her as the "whore", but it is ironically Finbar who becomes the "whore". Prostitution is a form of objectification of the body, which regards bodies as soulless "lumps of natural stuff", to borrow Eagleton's words. The danger of viewing the self as a disembodied soul is that the "spiritless" body is exposed to maltreatment and exploitation. Social objectification ("hole between my legs") dehumanises Vera and deprives her of an identity. Her existence, her body, is reduced to the "abstract status of commodities" 26 . Vera questions this process of social objectification, one that she has internalised in the form of self-objectification. Vera's regard for her body shows a type of schizophrenia, where she feels that her body is an alien appendage to her identity, dissociated from her soul.

24. Helen Meany, “The Wake Review - Response to Hidden Irish Histories is Fuelled by Fury”, The Guardian, 1 July 2016.

25. Alexandra Poulain, “My Heart Untravelled': Tom Murphy's Plays of Homecoming”, Études anglaises, vol. 56, n² 2, 2003, p. 191.

26. Terry Eagleton, Materialism, p. 59. 
As an act of defiance, Vera has not washed or brushed her hair for four days, and her slip is dirty. Finbar complains, "Wouldn't you think she'd get up! Wouldn't you think she'd! Get dressed! Wash herself!" (p. 112). Vera bluntly replies that since Finbar had sex with her twenty minutes ago, there is nothing for Finbar to complain about. Various social institutions including family, school and church (or the ideological state apparatuses, as Louis Althusser calls them) use discipline and labour as key tools to tame the body for subjugation. Vera's unwillingness to groom herself goes against disciplining the body and upholding "respectability". According to Finbar, "nice clean people" are the ones "at one another's throats after [...] the hotel over all their heads" (p. 113), referring to Vera's family. The characters' daily routine and rituals - of getting up, washing, dressing up - are disciplinary measures, bourgeois manners unconsciously accepted as life's necessities. Vera's refusal to manage her appearance liberates her from such oppressive norms. Moreover, signs of dirty creatures - woodlice, rats, cockroaches - overlap with the greedy deeds of the O'Tooles. Vera shouts, "Woodlice! The place is infested with them! [...] waddling their lives in the dark in the damp!" (p. 114). When Finbar tells Vera that her brother Tom will be bidding for the hotel at the auction, Vera retorts that "there's a rat about the place" (p. 115). The rat is "tawny, yellow, almost see-through, fast-moving strings of evil-looking fucking things that move in and out precisely" (p. 115). Finbar, who is described as "a frightened scavenger" (p. 85), steals money from Vera's wallet just as she is talking of cockroaches in New York. Descriptions of the insidious woodlice, rats, and cockroaches work as metaphors for these dirty, materialistic deeds.

It is helpful to see Vera as an embodiment of Julia Kristeva's notion of the “abject". Vera's presence disturbs the family (and by extension disturbed the audience) as their own sense of identity is confronted by the abject, which defies bodily boundaries, order and system ${ }^{27}$. Vera shares her experience as a call-girl:

I've been in situations you cannot even imagine. [...] Did anyone ever tell you to eat shit? Human excrement, shit. No? But I survived [...]. My Xanadus I call them. These can ease things. Human excrement, shit, shits, become more palatable with these. Working girls, friends of mine, use them on themselves. I don't use them on myself. I prefer to use them more for the purpose of taming a difficult client, anaesthetizing an animal. (p. 118)

Her experience of consuming human excrement upsets bodily boundaries - between the pure inside and the filth outside - and identity, which is formed by distinguishing oneself (the subject) from the excremental object. At another level, using drugs to tame an "animal" client destabilises the notion of what makes one human. It is also a reminder of Alasdair MacIntyre's point that "our whole initial bodily comportment to the world is originally an animal comportment" ${ }^{28}$. Moreover,

27. Julia Kristeva, Powers of Horror: An Essay on Abjection, Leon S. Roudiez (trans.), New York, Columbia University Press, 1982.

28. Alasdair MacIntyre, Dependent Rational Animals: Why Human Beings Need the Virtues, London, Duckworth, 1999, p. 49. 
Vera does not use the drugs on herself to anaesthetise the ghastly experience as a purely passive suffering but to turn her clients into objects. Her presence becomes more harrowing and proves that she has agency despite the limited circumstances.

The hotel space functions as a platform for Vera to make a spectacle out of her body, one that resists being made palatable or consumable for the viewers. In addition to the minimal setting, the 2016 performance did not frame the hotel space with high walls but left it open ${ }^{29}$. Its openness accentuated the liminal quality of the hotel, putting the audience in the position of the townspeople looking in at the shocking spectacle. The distinction between the interior and exterior - between private and public - was blurred. In the play, Vera's orgy at the hotel flabbergasts her family, the police and the priest. By foregrounding the hotel as an open performative space, the production encouraged the audience to engage with the characters' private matters and what they convey. The openness throughout the play was enhanced by the use of the scrim ${ }^{30}$. With the scrim, the orgy scene remained dimly visible throughout the family colloquy scene that followed. The audience became complicit voyeurs to the scene that was so scandalously burning itself into the consciousness of the O’Tooles. Anthony Roche argues that Murphy's female characters are socially marginalised and can assert themselves only in closed spaces. In a bigger normative world, they are physically and psychologically offered as a "sexual commodity to that masculine milieu" ${ }^{11}$. By deciding not to demarcate the interior space with walls throughout the whole play and having it exposed to the public, the production broke down the "normative space" of the "masculine milieu": the "marginal" women became the centre, asserting themselves openly.

According to Mariam Fraser and Monica Greco, the body serves as a powerful revolutionary tool in occasions where social hierarchies are transgressed and inverted. In these social occasions such as the carnival, fair, festival, masquerades and spectacles where customary rules of social conduct are suspended, "the body invaded the social scene as its most conspicuous actor, unrivalled in performing distortion and exaggeration - in other words, in the task of turning the world upside-down" 32 . Mikhail Bakhtin's idea of the grotesque body is that which is

29. This is in contrast with the 1998 set design by Francis O'Connor. After its premiere in the Abbey the play toured abroad in 1999. In a review of the 1999 Edinburgh Festival production directed by Patrick Mason, Paul Taylor wrote that the stage exhibited a "stark ghostly dreamscape, framed by high walls". See his article "Edinburgh Festival '99: Theatre Review 'The Wake”, The Independent, 19 August 1999.

30. A scrim is a net-type fabric commonly used in theatre alongside other types of theatre drapes and stage curtains. The direction and intensity of lighting can create variations in opacity of the scrim. When a person behind a scrim is lit from the back, the scrim becomes transparent (a process known as "bleed-through"); when lit from the front the scrim becomes opaque. For more details, see John Holloway, Zachary Stribling, Illustrated Theatre Production Guide, $4^{\text {th }}$ ed., New York, Routledge, 2020.

31. Anthony Roche, "Murphy's Drama: Tragedy and After", in Contemporary Irish Drama, $2^{\text {nd }}$ ed., London, Palgrave Macmillan, 2009, p. 124.

32. Mariam Fraser, Monica Greco, "Bodies and Social (Dis)Order", in The Body: A Reader, Mariam Fraser, Monica Greco (eds.), London, Routledge, 2005, p. 69-70. 
uncertain and fluid, "open, protruding, bulging, extending and secreting; wet, bloody, sweaty and odorous" 33 . Despite the celebratory, empowering and sensual aspect of the orgy scene (more evident in the novel), the performance retained the play's dark and grim tone. Vera's public display of her sexual body is antierotic; rather than being consumed by the audience in the form of spectacle, Vera's self-spectacularisation is abject and grotesque. The audience, therefore, experiences the felt presence of decay, corruption and terror exposed and voiced by Vera. As Emer O'Kelly puts it, "Aisling O'Sullivan is devastating in the role of Vera, a termagant railing against the destruction of everything she had clung to: the performance tears your heart out" ${ }^{34}$. The visceral experience of discomfort in theatre is a way to alert and awaken audience's bodily senses.

\section{"Waking" (for) the self and nation}

Compared to her prostitution in New York, Vera's sexual orgy in her hometown in which no monetary exchange is required is, to a certain extent, a hedonistic and purifying act to reclaim her body's materiality. Differing from the scene where she refused to wash or groom, Vera "has changed and done herself up. The dress is makeshift, but it creates the effect she wants: The marks of a whore and sexy" (p. 141). Wearing her mother's dress, Vera participates in the orgy not only to flaunt her sexuality and upset her family, but also to mark the occasion as celebratory. Vera wants to celebrate her birthday. Finbar wishes Vera a happy birthday, to which she declares: "Let's start the party" (p. 141-142). That it is her birthday (or so she claims) shows her need for human recognition, to be acknowledged and congratulated for being born and alive. This bodily affirmation is elaborated in the novel, in the chapter "There Is Nothing so Futile as Planning for Pleasure":

It was her thirty-eighth birthday and she was enjoying it. [...] She was celebrating her sexuality, nourishing it. But it was not only a matter of her sexuality. [...] She felt different. She felt loose. She was not wearing any make-up. In the day that had passed she had shed some illusions, slipped out of folds of the past and, at home, she was tasting the lightness and freedom of becoming herself. She had moved out to a new place. [...] She was on her own. [...] she was exhilarated. In a way, she felt naked. She was laughing again: at what, she was not sure; but she could hear the ring of truth in the sound of her voice ${ }^{35}$.

Vera finds her identity and freedom in the state of nakedness. From the state of depressed confusion to wild celebration, Vera goes through a subtle but progressive change. Although she cannot erase her sense of self-degradation and shame totally

33. Mikhail Bakhtin, Rabelais and His World, Hélène Iswolsky (trans.), Bloomington, Indiana University Press, 1984, p. 319-320; quoted in Mariam Fraser, Monica Greco, "Bodies and Social (Dis)Order", p. 70.

34. Emer O'Kelly, “Theatre: Wreaking Havoc on Small-Town Rituals”, Irish Independent, 4 July 2016.

35. Tom Murphy, The Seduction of Morality, London, Little Brown, 1994, p. 142-143. 
through this single occasion, it marks a change in the way she regards herself and her body: an individual self to celebrate and not a thing to sell.

The changes in setting complemented Vera's own search for her identity. In a review of the 2016 production, Peter Crawley summarised: “As Vera tries to find her place in this world, we begin with a vast backdrop of the cosmos, slowly stiffening into a monochrome map of Tuam, resolving, finally, with a hole in the ground" 36 . A screen monochrome (ordnance survey) map of Tuam featured in the background was initially difficult to discern, but when it was illuminated in the play's climax, place names of the townland were revealed. The narrative of the play is rooted in a specific time and place, and the map highlighted the fact that the characters are a "product of a culture" (p. 85). The history of the ordnance survey (whose function was to assist armies with the movement of heavy artillery as well as land valuations for taxation purposes) stretches back to the early $19^{\text {th }}$ century, from the establishment of the Ordnance Survey office in 1824. From imperial history to a post-colonial Ireland, land has been appropriated and expropriated as commodity in the process of capitalism. The map pointed to the ways people use various tools and instruments to measure and justify their avarice.

As revealed in the characters' story, the map also spoke to the "hidden histories" of Ireland: confinement culture, institutionalisation, corrupted clerical power, abuse of children in industrial schools and the hypocrisy of the wealthy. The choice of Tuam in particular resonated with Irish audiences and the diaspora because of the recent discovery of an unmarked mass grave - allegedly of up to 800 babies and children - in Bon Secours Mother and Baby Home ${ }^{37}$. An interviewee and survivor from Bon Secours described her experience there in these words: "Like chickens in a coop" 38 . This is yet another example of bodies being dehumanised and maltreated. Finbar shares his traumatic experience of being abused by the Christian Brothers:

Sex! [...] And fuckin' incest! Driving round the country, screwing young ones in their Volkswagens, then going home ("and") doing their housekeepers - Sex! Christian Brothers in the schools - (Intensely, to himself:) Faaack! Beating the children, Henry, then buggering them: I was "in care", Henry, them establishments, [...] And young ones and aul' ones getting pregnant and praying to fuckin' statues about it. Country is rotten with it. [...] But what else was the country taught to think about? (p. 140)

36. Peter Crawley, "The Wake: Performance and Design as Pure Poetry”, The Irish Times, 29 June 2016.

37. Jamie Grierson, "Mass Grave of Babies and Children Found at Tuam Care Home in Ireland", The Guardian, 3 March 2017. Following the work of local historian Catherine Corless, the issue received much public attention with a judicial commission of investigation into Mother and Baby Homes established in 2015. The Mother and Baby Homes Commission of Investigation's final report was published on 12 January 2021 by the Department of Children, Equality, Disability, Integration and Youth. An estimated 56,000 women and 57,000 children in Ireland were placed or born in the homes between 1922 and 1998. Approximately 9,000 children died. The full report is available here: http://www.mbhcoi.ie/mbh.nsf/page/index-en.

38. Dan Barry, “The Lost Children of Tuam”, The New York Times, 27 October 2017. See also Mike Milotte, Banished Babies: The Secret History of Ireland's Baby Export Business, Dublin, New Island, 1997; updated and revised in 2012. 
Vera's incarceration in a mental asylum equally fits into the larger picture of the "culture of confinement" history in Ireland ${ }^{39}$.

The hidden horrors of Irish history were brought to light by the set design, yet a set device was deployed to suggest that the specificity of the Irish experience does not exclude its universal significance. The vastness of the screen with its surreal blue texture expanded to the mythic world. Even though the place names appeared on the screen, the enlarged size of the map made the lines form geometrical shapes. The lines and shapes, which are not confined to Irish history, appeared to be a side of earth seen from outer space. The magnification of the map to the extent of sur-reality had the effect of subverting the human practice that subjects land to instrumental rationality, with mapping being a quintessential example of such practice. When the audience were faced with a familiar map in an unfamiliar fashion, they were transported into a strange and ghostly landscape that drew on Freud's idea of the uncanny or unheimlich, which in its German roots means both "un-homely" and "un-secret" ${ }^{40}$. Freud builds on Schelling's definition that "Uncanny is what one calls everything that was meant to remain secret and hidden and has come into the open" ${ }^{41}$. Vera's "home"-coming is met with family secrets, scandalous events and stories repressed in history being unveiled in the open theatre space. By using a large surreal ordnance map, the set managed to point to a specific history as well as a universal aspect of humankind.

The wake takes place in the hotel as a belated family reunion and celebration; as the play reaches its climax, the eponymous wake for Mom completes the imagery of the O'Toole family as "whores", "playing up to Vera for the property they crave" 42. The deceased is, significantly, neither present nor mentioned throughout the whole wake. The wake assumes its importance not in remembering or paying respects to Mom, but in bringing together hate-filled family members in one place. Each family member performed their own party piece in their preferred genre, from jazz, operetta, to Irish poetry. As Grene notes, the 2016 production made the wake seem like a "grotesque parody", especially when Lorcan Cranitch as Tom and Pat Nolan as Father Billy sang "The Moon Hath Raised Her Lamp" in duet, "milk[ing it] for every possible laugh" 43 . Grene argues that this misses the ambiguity of the scene's tone, in which the family "redeem their innocence" (p. 167) through their

39. Henry McDonald, “'Endemic' Rape and Abuse of Irish Children in Catholic Care, Inquiry Finds”, The Guardian, 20 May 2009. For more information, see Coercive Confinement in Ireland: Patients, Prisoners and Penitents, Eoin O'Sullivan, Ian O'Donnell (eds.), Manchester, Manchester University Press, 2012 and James Smith, Ireland's Magdalen Laundries and the Nation's Architecture of Containment, Notre Dame, University of Notre Dame Press, 2007. Smith argues that the "architecture of containment" has been constructed in both concrete and abstract ways: in addition to an array of different but interdependent institutions such as the industrial schools and reformatory institutions, which had an executive function, a series of legislative acts and official discourse functioned to render these embodied "culprits" invisible.

40. Sigmund Freud, The Uncanny, David McLintock (trans.), London, Penguin, 2003, p. 124-125.

41. Ibid., p. 132.

42. Nicholas Grene, The Theatre of Tom Murphy..., p. 95.

43. Ibid. 
own songs ${ }^{44}$. Indeed, at one of the performances, when the climactic action of the wake took place, the audience began to clap along with the other characters on stage after each individual party piece ${ }^{45}$. While the audience's laughter and applause testified to the parodic and ironic element of the wake scene, it equally showed how the audience were made complicit in the whole performance, not necessarily laughing "at" but "with" the members on stage. It could be argued, therefore, that the multiple performances within the wake scene made the audience engage with and acknowledge the wake ritual as a temporary bonding experience that brought together the actors-as-characters and the audience. It is this theatrical moment that transforms Augé's "non-place" into the anthropological "place", whereby an organic theatrical community is formed. It is not traditional family values but theatrical temporality that offers the possibility, however flickering, of communal bonding: only in these shared temporal moments (as in the ephemeral moments of theatre) can meaningful interaction take place.

The climactic wake scene in the 2016 production stressed the theatricality and performativity of the communal ritual, one that did not affirm but deconstructed the myth of family and community. The wake is a form of collective mourning but in Murphy's play it is only in isolation that one can achieve any kind of understanding of the self. In the last scene, Vera is able to truly grieve:

[...] now she is crying. Tears that she cannot stop, that she has been suppressing throughout. She begins to sob. Her sobbing continues, becoming dry and rhythmical: Grief for her grandmother, for the family that she perhaps never had, and for herself and her fear at this, her first acceptance of her isolation. (p. 180)

This cry is resonant of the traditional practice of keening, an intrinsic part of the wake ritual: from the Irish word caoine or caoineadh, meaning "vocalised cry", keening is "a sacred improvised chant that evolved over many centuries [...] traditionally sung over a corpse" and is "a descriptor for the instinctive raw cry that is often the first reaction of the bereaved to death" ${ }^{46}$. In the actual production, the sobbing continued for an extended period and marked a stark contrast to the hullaballoo of the wake scene. Transcending the limits of lyrics and language, the rhythmical sobbing became pure sound and the crying became a grieving song for the wake: a one-person wake truer to its meaning of grief for her grandmother, her family, herself and for the impossibility of a communal wake.

The play has a frame structure: it begins with the scene of Vera's meeting with Mrs. Conneeley in an open space and ends with their meeting at the graveyard. Scene

44. Nicholas Grene, The Theatre of Tom Murphy..., p. 95.

45. Date of performance attended: 27 June 2016.

46. Mary McLaughlin, “Keening the Dead: Ancient History or a Ritual for Today?", Religions, vol. 10, no. 4, 2019, p. 235. More recently, the tradition of keening has been given renewed prominence by Doireann Ní Ghríofa's A Ghost in the Throat (2020) which draws on Eibhlín Dubh Ní Chonaill's "Caoineadh Airt Uí Laoighaire" (“The Lament for Art O’Leary”), a well-known $18^{\text {th }}$ century Irish poem. 
One begins in "an open space: the country. Night" (p. 77). On stage, a small array of lights denoting stars dotted the dark background. The opening mise-en-scène was indicative of the peaceful and natural countryside as there were no city lights to prevent the protagonist (from where she stands) from seeing the stars. It played on Vera's projection of home/home-coming both as "dream" and "nightmare" (p. 82). Furthermore, the set created a surreal atmosphere of "the cosmos", a universe on its own. Vera with her urban outfit seemed in contrast with the country background. The discrepancy between the background and the figure immediately set her as an outsider, even an alien. As her lines indicate, Vera's desire to belong has always eluded her: she feels "Out there in the space like a fucking astronaut with his tube cut. [...] Lifelong fear of just going to sleep, afraid to let go" (p. 117). In the end, however, Vera embraces loneliness and feels liberated, having cut her ties with the family.

While Vera's emigrant status highlights how alien she is, Mrs. Conneeley represents the grounded nature figure. In the stage directions, Murphy describes her as "an unassuming woman; she has a lot of integrity, a lot of what used to be called 'nature"' (p. 77), which also means, in Irish usage, good nature. Mrs. Conneeley is thus a good-natured woman as well as a nature-bound one. By contrast, as Murphy put it in the draft of the play, the O'Tooles are "people starved of 'nature' being withered by greed and materialism" ${ }^{47}$. Mrs. Conneeley differs from the other characters. At the end of the journey, Vera meets Mrs. Conneeley at the graveyard. Her presence in the graveyard seems fitting as she is closest to nature and death. Played by Ruth McCabe, she was presented as the classic country woman: short white hair, wearing a brown cotton dress with floral patterns and a brown cardigan over it with a dark green anorak on top. Rid of all the furniture and with minimum lighting, Mrs. Conneeley, Vera and the hole in the ground only occupied a small portion of the dark stage set. They were engrossed in the environment yet seemed comfortable in the space. The 2016 performance tellingly showed that graveyards not only signify death but also human "nature" and its desire to become part of earth.

Despite the graveyard's association with nature, its meaning is ambivalent. Funeral rituals for the burial, tombs and headstones to mark and commemorate a person are all part of a human-made culture and not nature. Graves are another way of marking and displaying territory and wealth. Materialism is inescapable even with death. Mrs. Conneeley points out that the graveyard where her husband is buried is getting crowded. She remarks: "I never bothered to mark it. (Dismissive:) Ah, headstones! What is it but an aul' hole in the ground!" (p. 180). She also mentions: "Oh and there's many's the widow-woman knocking about, waiting to get in here. And what at all in the next world would I do if they put another woman down on top of him before me?" (p. 180). Mrs. Conneeley says she is not interested in the territorial demarcation. She even jokes about her husband's posthumous extramarital affair underground with another dead woman (the thought of which immediately

47. Nicholas Grene, The Theatre of Tom Murphy..., p. 91. 
arouses jealousy in her). Those are only human projections of their own thoughts onto the dead. Mrs. Conneeley's act of weeding and minding the grave "like someone preparing a bed" (p. 180) shows her poised acceptance of death as part of life.

\section{Conclusion}

In an interview with Michael Ross in 1998 regarding The Wake, Murphy commented:

We all deny our isolation. We prop ourselves up with ideas of family, marriage and so on. The other characters in the play try to deny their sense of isolation in the same way that people deny their sense of mortality by a mania for accumulating things ${ }^{48}$.

Denial of one's isolation results in the indulgent dependency on various illusory myths and ideologies, and denial of one's mortality manifests itself as material acquisition to fill the void. With its themes at once existential and social, abstract and real, the 2016 production served as a timely mirror of what had or had not changed in Ireland since Murphy first wrote the play. The Wake is a portrayal of materialism and how it has affected Irish society - an obvious and even clichéd topic, yet surprisingly not so often dealt with in modern Irish theatre. Murphy focuses on the woman's body as the site of contestation and identification. The female body once again becomes a metaphor for the state of the nation, and figurations of woman / nation function as a scathing commentary on contemporary Irish society. Materialism represses and erases the materiality of the body. Vera's homecoming becomes a journey of self-realisation and self-transcendence. Rejecting society's mind-body dualism, Vera sees herself as an active body, a source of expressive vitality, meaning and autonomy. Her homecoming clashes with social norms and she exploits the confrontation as an opportunity to reclaim her body and re-establish her identity. The ritual of the traditional Irish wake finds a new meaning in theatre as a celebratory and temporary communal experience: the 2016 Abbey production of The Wake was not only a timely reflection of contemporary Ireland but also a glorious send-off and grieving for the bodies brutally exploited, buried and forgotten in people's lives.

Moonyoung HoNG

Trinity College Dublin

48. Michael Ross, "Prozac? No Thanks: Depression is Tom Murphy's Propelling Force", The Sunday Times, 25 January 1998. 